\title{
Phenylpropanolamine Hydrochloride
}

National Cancer Institute

\section{Source}

National Cancer Institute. Phenylpropanolamine Hydrochloride. NCI Thesaurus. Code C66379.

The hydrochloride salt form of phenylpropanolamine, an alpha- and beta-adrenergic receptor agonist with sympathomimetic activity. Phenylpropanolamine binds to and activates alpha- and beta-adrenerg ic receptors in the mucosa of the respiratory tract resulting in vasoconstriction and reduction in swelling of nasal mucous membranes and reduction in tissue hyperemia, edema, and nasal congestion. This agent also stimulates the release of norepinephrine from its storage sites resulting in the effects already described. Finally, phenylpropanolamine indirectly stimulates beta-receptors producing tachycardia and a positive inotropic effect. 